\title{
EDUARD SCHWEIZER
}

\section{OBSERVANGE OF \\ THE LAW AND GHARISMATIC ACTIVITY IN MATTHEW*}

The topic of my paper is particularly suitable for a Presidential Address to our Society, because so many of you have contributed, in no inconsiderable way, to the elucidation of its problems. What I shall try to do is simply to bring together some of the results of your work and then to build upon them. We have, in our common research, reached a point where it makes sense to look back on what we have discovered and to put up some signposts to mark our future course. When I say so, it is not merely an act of politeness; it is rather the expression of my appreciation of so many contributions from you without which my understanding of the first Gospel would not have been possible. Some I am able to mention, some not, but for all of them I remain grateful. And my thanks are most sincerely felt, because I know of periods of loneliness, even of depression, that every scholar experiences when thinking that all his work leads nowhere. Therefore I want to emphasize here how often an observation of one of my colleagues, small and unimportant as it might have looked in itself, has opened my eyes and given me new courage to go on my way, or has brought me out of a cul-de-sac of research work.

I presuppose in the following essay that Matthew has used Mark and $Q$. $Q$ is considered a stratum with traditions in different stages, oral and written, rather than one definitely written source.

I am particularly interested in our theme, because I am concerned about the understanding of the Church in our Gospel. The problem is put, at a point of particular emphasis, at the end of the Sermon on the Mount, by the sentence of the divine Judge upon those who refer to their charismatic activities. It is those who (no doubt truthfully) boast: 'Lord, Lord, have we not prophesied in your name, cast out demons in your name and done many mighty works in your name?', to whom the Judge answers: 'Never have I known you; away from me, you doers of iniquity' (vii. 22 f.). Does this mean that Matthew sides with a Jewish Christianity strictly bound to a literal observance of the Law and opposed to the more charismatic life of a Hellenistic church? What is the relation of charismatic activity to legal obedience in Matthew?

* Presidential address at the S.N.T.S. meeting in Frankfurt/Main, 12 August 1969, originally presented in a shorter German version (cf. E. Schweizer, Neutestameniliche Aufsätze, 1970, nr. 4). 


\section{THE LAW}

There is no doubt that the question of the Law plays an important role in Matthew. 'Until heaven and earth pass away, not a single jot or tittle of the Law will pass away' (v. I8). 'On the chair of Moses the scribes and Pharisees are sitting. All that they tell you, do it and keep to it; but do not imitate their works, for they say so without doing so' (xxiii. 2 f.). To be sure, these are traditional sentences taken up by Matthew, as is proved, in the first case, by the parallel in Luke, in the second, by the analysis of the chapter which has been undertaken, among others, by E. Haenchen. ${ }^{1}$ Though this means that we are to focus our attention on the interpretation given by the Matthean context we have, before doing so, to see that in some way Matthew agrees with his tradition. More important are redactional phrases like the famous addition in xxiv. 20 praying that, in the latter days, the flight of the people of God might not happen on a sabbath. Again it is possible or even probable that Matthew knows this variant of the Marcan sentence from the tradition in his church. And yet he inserts this addition consciously, which is proved by his changes in xii. I-I4 transforming Jesus' offences against the law of the sabbath into mere exceptions possible within still valid rules, as Dr Carlston has shown recently. ${ }^{2}$ Thus the main question for Matthew is in what way the law of Moses is to be obeyed.

Dr Bornkamm has demonstrated, some time ago, that for Matthew the law is still valid in its interpretation by Jesus' doctrine and conduct. ${ }^{3}$ Thus, the Matthean context in which v. 18 stands is illuminating. In Luke the beatitudes (and woes) are followed immediately by the commandment not to avenge oneself, but to love one's enemy. ${ }^{4}$ Matthew, on the contrary, inserts first some logia about true discipleship with the illustrations from salt, light and a mountain town, ${ }^{5}$ and then deals fundamentally with the problem of the Law, including our saying in $v$. 18 , in order to present the new and better righteousness in six antitheses, among which the two Lucan logia are to be found at the end. Not to avenge oneself but to love one's enemy means, for Matthew, obedience to the Law in the new and better way of the disciples of Jesus. This is interpreted by the initial statement of verses i 7-20 that Jesus fulfils law and prophets and that, therefore, the righteousness of his disciples should be better than that of the Pharisees. I still think that the

1 'Matthäus 23', Z.T.K. XLviı (195I), 39 f.

2 'The Things that Defile (Mark vii. 14) and the Law in Matthew and Mark', N.T.S. xv (1968/9), $86 \mathrm{f}$. The rule of the priority of mercy over cult (Matt. xii. 7) applies to this case, because the disciples 'were hungry' and had to 'eat' (Matthean addition). Cf. also the insertion of verses II, $12 a$ and p. 220 n. 3 here.

3 'Enderwartung und Kirche im Matthäusevangelium', in: G. Bornkamm, G. Barth and H. J. Held, Uberlieferung und Auslegung im Maithäusevangelium ( 1960 ), $29 \mathrm{ff}$.

- Luke has inserted the former saying into the latter one. The change between singular and plural of the second person of the verb shows that this is a secondary development.

5 Cf. R. Schnackenburg, 'Ihr seid das Salz der Erde, das Licht der Welt', in: Melanges E. Tisserant, I ( $\left.\mathrm{g}^{6} 64\right), 3^{6} 5 \mathrm{ff}$. 


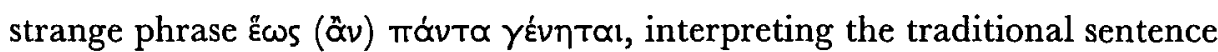
'until heaven and earth pass away, not a single jot or tittle of the law will pass away', refers to the fulfilment of the Law by Jesus and his Church. ${ }^{1}$ The double $\tilde{\varepsilon} \omega s$ is certainly difficult to understand. However, $\tilde{E} \omega s$, particularly if Codex Vaticanus is right in omitting ơ $v$, expresses very often 'the expectancy' of a future event and comes close to a final particle. ${ }^{2}$ We may, for instance, compare Matt. xiv. 22: 'He urged the disciples to enter the boat and to precede him to the other shore, that he might, in the meantime, dismiss the people.'3 If so, Matthew's interpretation becomes clear: 'Until heaven and earth pass away, not a single jot or tittle of the Law will pass away, that (up to that time) all (that the Law asks) will be done.' In this sense Jesus has come to fulfil law and prophets. Doubtless Matthew understands fulfilment in the sense of an active obedience to the Law, as it is now interpreted by Jesus. This is shown by the contrast in the following verse between 'to relax' and 'to do' one of these commandments. In both halves of the verse the position of 'to relax' or 'to do' before 'to teach' stresses the importance of the former act. ${ }^{4}$ Moreover, 'these commandments' refer, as Dr Carlston has rightly observed, ${ }^{\mathbf{5}}$ to the antitheses of Jesus which follow immediately. This is exactly what the great commission at the end of the Gospel means, when inviting all nations to become disciples of Jesus by keeping all that he has commanded. Thus, the Law of Moses, interpreted by Jesus in his teaching and his whole activity, remains valid for the Church of Matthew. As, in the Old Testament, it is God's gift of the covenant which makes it possible for His people to obey Him, so it is Jesus' ministry which enables the Church to follow him.

In this sense, even the sabbath is still to be kept, though in a modified way, since Jesus gave prior importance to mercy and allowed for exceptions whenever charity made them necessary. However, on the whole, he kept to the sabbath rules of Israel, and his Church should not act otherwise. Thus, only the suffering neighbour who needed help would excuse the breaking of the sabbath, since Jesus undoubtedly put love higher than a literal observance of the sabbath. We should never forget how little we know about the observance or non-observance of sabbath in the different parts of the early Church. In any case, in the Fourth Gospel the problem of the sabbath is still vital (v. 9, I6; ix. I4) and seems, as Dr J. L. Martyn describes it, ${ }^{6}$ to separate

1 Cf. E. Schweizer, 'Matth. 5, I 7-20 - Anmerkungen zum Gesetzesverständnis des Matthäus', in: E. Schweizer, Neotestamentica (1963), pp. 399-406.

2 A. T. Robertson, A Grammar of the New Testament (1914), p. 976. Extrabiblical examples of a final zos: F. Blass and A. Debrunner, Grammatik des nettestamentlichen Griechisch (1943), §375, appendix; Liddell and Scott s.v.; E. Schwyzer, Griechische Grammatik $\left({ }^{2} 1959\right)$, Pp. 650 f. 洎 ${ }^{\mathrm{Pag}}{ }_{1}{ }_{1} 8$, I2 (second century A.D.) proves (against E. Mayser, Grammatik der griechischen Papyri, I1/1 (1926), p. 270) that the main clause may well be expressed in a present tense. $z \omega s c k$ is not to be found earlier than Test. Iobi xxi. 2 ; xxii. 3 in a definitely final sense, but Matt. v. 26 probably implies a final meaning.

- Carlston (see p. 214 n. 2), p. 80

The parallel in Mark vi. 45 contains no oṽ.

- History and Theology in the Fourth Gospel (1968), pp. 54 ff. 
the Johannine Ghurch from a Judaism sympathizing with Jesus or even from a Jewish Christianity (viii. 30-2). At the end of a long discussion of Jesus with the representatives of a legalistic view, Matthew's addition in xv. 20 declares that all this has to do with the question whether or not to wash one's hands before eating. This certainly does not mean that Mathew still defends the food regulations which once separated Jews and non-Jews; otherwise he could not have repeated the saying of Jesus that nothing which enters through the mouth could make man unclean. It does mean, however, that, in the view of Matthew, not simply the Law, but merely a certain Pharisaic and scribal interpretation, was attacked by Jesus. ${ }^{1}$

If we ask about the content of this new interpretation of the Law by Jesus, we may say, without dealing with all the problems involved, that the commandment to love one's neighbour is for Matthew the key that opens the new understanding of the Law. Twice this commandment has been stressed (xxii. 39) or added (xix. $19 b$ ) in Matthew's redaction. Twice Matthew explains Jesus' attitude towards the Law by the saying of Hosea, 'It is mercy and not sacrifice that I want' (ix. I 3 ; xii. 7), and it is remarkable that he chose this word and not the variant of I Sam. xv. 22, 'Obedience is better than sacrifice'. Twice charity or the golden rule is explicitly declared the content of 'law and prophets' (xiii. 39 f.; vii. 12). Perhaps even more important is xxiv. I $\mathrm{I}$, for here Matthew tells us exactly what, in his understanding, the o'vouía which leads to the final condemnation consists of. Into the little Marcan apocalypse Matthew has inserted a warning against the false prophets who will bring the ơvouí to its fullness, namely to the cooling off of all charity. ${ }^{2}$ So important is this for Matthew that in his redaction the faithfulness up to the end is no longer one which is exercised in times of persecution but the steadfastness against temptation by the false prophets, leading away from a life of real charity.

\section{GHARISMATIG ACTIVITY}

This leads us to the decisive question, who are these charismatic workers against whom Matthew fights?

Dr W. D. Davies is right in rejecting Lagrange's opinion that they are Jewish opponents called false prophets in an Old Testament figure of speech.

\footnotetext{
1 Also, R. Walker, Die Heilsgeschichte im ersien Evangelium ( $19^{6} 7$ ), pp. I 6 6-1 8, stresses the radical concentration on the doctrine of the earthly Jesus. If $\mathrm{H}$. Baltensweiler, 'Die Ehebruchsklauseln bei Matthäus', T.Z. XV (1959), 340 ff. were right in his thesis that the clauses in Matt. v. 32 and xix. 9 were directed against marriage with relatives as forbidden by the book of Leviticus (so that such wives should be divorced before baptism), the conservative legalism would be evident (similarly E. P. Blair, Jesus in the Gospel of Matthew ( 1960$)$, pp. 42 and 157 ff.). In spite of Acts xv. 20 (= Lev. xvii. 10-16 and xviii. 6-18?) this remains questionable.

Walker, op. cit. pp. $134 \mathrm{f}$. sees correctly that this is not directed against an explicit antinomianism; the false prophets, however, are described twice as the doers of \&voula, i.e. as Christians of an easy morality. Emphasis on charity also in W. Trilling, Das wahre Israel (1964), pp. ig6 ff.
} 
They are certainly Christians. ${ }^{1}$ Also C. F. D. Moule, thinking that the discussion with Jewish opposition to Christian libertinism plays an important role in the first Gospel, sees in the condemned false prophets of vii. $22 \mathrm{f}$. Christians. ${ }^{2}$ Can we describe them more accurately? Scholars agree that they are not typical Gnostics, since there is no anti-gnostic polemic in the first Gospel;3 nor are Paul and his church hinted at, as Dr Davies and Dr Hummel rightly contest against Dr Brandon. ${ }^{4}$ Should we content ourselves with the label 'Hellenistic libertinists'?5

The Matthean summary in iv. 23 and ix. 35, forming the frame around the picture of Jesus as the Messiah of word and deed, puts the 'halachic' teaching of the law and the gospel of the kingdom, in the words of Dr Bornkamm, side by side. ${ }^{6}$ The particular importance of the 'Gattung' of the words of wisdom in our Gospel has been stressed by Dr James Robinson.? Even more important seems to me the careful investigation of the term $\varepsilon \dot{v} \alpha \gamma \gamma \dot{\varepsilon} \lambda_{1}$ ov and its use in the pre-Pauline strata by Dr Stuhlmacher. It brought us a definite step forward. Twice the Gospel is, in Matthew, explicitly defined as the Gospel of the Kingdom (which becomes even more important when we see that the Sermon on the Mount, which is introduced by this term in iv. 23, defines in its turn what this means); twice it is called 'this Gospel' or 'this Gospel of the Kingdom'; twice the term found in the Marcan text is omitted by Matthew so that his text focuses on Jesus and his name only. This means that Matthew is obviously reluctant to speak of the 'Gospel' without clarifying what he means by this term. When he writes 'this Gospel', he refers clearly to Jesus' teaching, to his proclamation of the Kingdom, either in one of the five sermons or in his whole doctrine. ${ }^{8}$ This fits well into the Matthean general solution of the problem of the Law, in which the whole conduct and teaching of Jesus is the standard of interpretation.

We detect, however, that this standard does not only draw the borderline against the past, the Mosaic Law and its Pharisaic interpretation, but also against the future, a post-Easter exegesis by a Church for which Jesus' own deeds and teaching would no longer be of unambiguous authority. In modern terms: Matthew is definitely sceptical about a kerygma-theology, in which the Gospel would be totally identified with the preaching after Easter without being safeguarded by a strict faithfulness to Jesus' own teaching.

This tendency becomes clearest in the two passages which speak explicitly about the proclamation of the gospel after Easter. In the little apocalypse,

1 W. D. Davies, The Setting of the Sermon on the Mount (Ig63), pp. Igg $\mathrm{f}$.

2 'St Matthew's Gospel: Some Neglected Features', in: Studia Evangelica, II, ed. F. L. Cross, T.U. Lxxxviı (1964), 92-4. $\quad$ s Davies, op. cit. pp. Ig9 f.; also Barth (see p. 214 n. 3), p. I53.

4 Davies, op. cit. pp. 333 f.; R. Hummel, 'Die Auseinandersetzung zwischen Kirche und Judentum im Matthäusevangelium', $B . e v$. Th. xxxıII ( $\left.196_{3}\right), 65$.

5 Hummel, op. cit. pp. 65 ff.; Barth (see p. 214 n. 3), p. 152. ${ }^{\circ}$ Bornkamm (see p. 214 n. 3), p. 35 n. 1 .

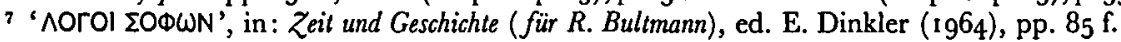

B P. Stuhlmacher, Das paulinische Evangelium (1968), I, 24 I f. 
the Marcan sentence about the proclamation of the gospel to all nations is corrected into a word about the proclamation of 'this gospel of the kingdom' -meaning again Jesus' teaching-in the whole world as a testimony to all nations before the coming of the end, so that the teaching of Jesus makes the nations responsible in the coming Last Judgment. More explicit is the great commission, just because this pericope deals, according to $\mathrm{Dr} \mathrm{A}$. Vögtle, with the institution of the Church rather than with the appearance of the

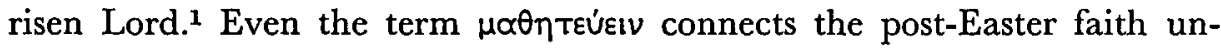
mistakably with discipleship under the earthly Jesus. Moreover, the presence of the risen Jesus in his Church is explicitly and centrally dealt with. Without any break this presence of the risen Lord on the mountains of Galilee seems to be continued in the promised presence with his disciples to the close of the age. It is even questionable whether or not this is conceived of in any fundamentally different way from the presence with the eleven on the Galilean mountain. This, however, is his presence in his commandments with all those that shall be taught to observe all that he, the earthly Jesus,

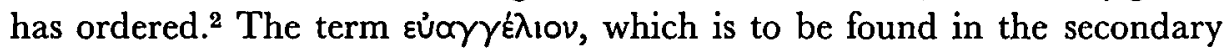
ending of Mark (xvi. 15), is missing here, as is typical for Matthew. We should not draw too far-reaching conclusions from this, however, since we cannot be sure whether there was a common tradition in the background of both texts, or what it was like, if there was one.

This shows that Matthew is struggling with the same problem as Paul and Luke, and in some sense also John. It is the enthusiastic life of a faith which is living by the experience of the risen and exalted Lord and the present activity of the Holy Spirit, but, at the same time, threatens to become more and more remote from the teaching of the earthly Jesus and the standard of his conduct. This has led Paul to stress his apostolic authority, to concentrate on the proclamation of the crucified Christ, and to differentiate very distinctly between the appearance of the risen Lord near Damascus and mere visions, imposing as they might be, like those of II Cor. xii. This has led Luke to a sharp distinction between the Twelve, who accompanied Jesus from the beginning of his ministry, and all those who have been called after the Ascension. This has led Mark to write a Gospel in which the life and especially the death of Jesus become important. This has led John not only to choose the form of a Gospel, but also to describe the Paraclete as the one who reminds the disciples of the words of the earthly Jesus (xiv. 26); and much as the first letter of John insists on the fullness of wisdom of the children of God, who need no teacher besides the Holy Spirit (I John ii. 27), it still knows that this one will teach them nothing but what had been taught 'from the beginning' (i. I, etc.). Thus, they are all forced to combat an

1 'Das christologische und ekklesiologische Anliegen von Mt. xxviii. 18-20', in Studia Evangelica, II (see p. 2 I 7 n. 2), pp. 279 f. Cf. also H. Kasting, Die Anfänge der urchristlichen Mission (I 969), pp. 34-8 (for the Matthean emphasis on $\mu a 0 \eta$ revelv, p. 36); Trilling (see p. 216 n. 2), pp. $49 \mathrm{f}$.

Cf. also G. Baumbach, 'Die Mission im Matthäusevangelium', T.L.Z. xcir ( (g67) $^{2}$, 889-93. 
uncontrolled prophetism rather than the dullness of a dead church, in which the spirit has ceased to act. How does Matthew set about solving this problem?

Dr W. D. Davies speaks of Matthew as the representative of a Galilean enthusiasm over against the realism of the rabbinic school in Jamnia. ${ }^{1}$ In so saying, he thinks of words like 'Do not be anxious about your life...' (vi. 25-34), which are taken up by Matthew from his tradition and, rightly or wrongly, considered to be sayings of Jesus himself. Hence this observation shows how much Matthew differs from the interpretation of the Law in Jamnia, but contributes nothing to an elucidation of his attitude towards a post-Easter prophetism in the Church of Jesus. Dr G. Strecker, however, has pointed in one of his footnotes to the definitely positive evaluation of prophecy and charismatic deeds in the first Gospel, ${ }^{2}$ and $\mathrm{Dr} \mathrm{Ph}$. Vielhauer argues that the very warning against false prophets presupposes the activity of genuine prophets in the Church. ${ }^{3}$ Dr Held's remarks lead still further. We have already referred to the summary which in iv. 23 and ix. 35 frames the picture of the Messiah in word and deed. It describes him as teacher of the gospel of the Kingdom and as healer of every disease and every infirmity. Immediately afterwards, in $x$. $\mathrm{r}$, the disciples are sent with authority to heal every disease and every infirmity. ${ }^{4}$ The literal repetition of this phrase shows how much Matthew regards their charismatic activity as the continuation of that of Jesus himself. Thus, it is just this charismatic healing in which discipleship expresses itself. In their preaching they repeat Jesus' proclamation of the imminent Kingdom; in their charismatic healing they act on the authority of Jesus himself: 'Heal sick men, raise dead ones, cleanse lepers, cast out demons' (x. 7).

Even more illuminating is Dr Held's second point. In chapters viii and ix Matthew collects miracle stories from the tradition in Mark and $Q$. At the end he adds, with obvious difficulty, two more, the healing of two blind men and of a dumb one, simply copying, with slight alterations, two other stories which he will tell later in his Gospel and could not omit there. ${ }^{5} \mathrm{He}$ does so because the word of Jesus, 'Tell John what you hear and see: Blind men regain their sight, and lame ones walk, lepers are cleansed and dumb ones hear and dead ones are raised and to poor people the gospel is preached' (xi. 5), must be fulfilled literally, for it is just these two miracles in the list of Jesus which are lacking in the material from Mark and $Q$ collected in chapters viii and ix. If so, the position of the pericope about the question

1 Davies (see p. 217 n. 1), p. 300 , cf. p. 256.

s Der Weg der Gerechtigkeit, F.R.L.A.N.T. Lxxxn (1962), I 37 n. 4.

3 R.G.G. ${ }^{3}$ v, 634; cf. Bornkamm (see p. 214 n. 3), p. $3^{6}$ n. $\mathrm{I}$; idem, 'Der Auferstandene und der Irdische', in: Zeit und Geschichte (1964), p. 180.

- Held (see p. 2 I 4 n. 3), pp. $237 \mathrm{f}$.

5 The healing of the two blind men in xx. 29-34 prepares the entry to Jerusalem and the Passion, the miracle in xii. 22-4, the discussion about Beelzebul. In the latter case ix. 32-4 speaks of a mute (cf. Luke xi. 14 f.), not of a blind and mute man, as xii. 22 does. 
of the Baptist and Jesus' answer becomes very striking. Why does it not follow immediately after the collection of the miracle stories, at the end of chapter ix? The answer is clear: Matthew inserts first, in chapter $x$, the call of the disciples and the conferring on them of the authority of Jesus to heal the sick, to raise the dead, to cleanse the lepers and to cast out demons because in the charismatic activity of the Church the deeds of Jesus which will convince the disciples of John continue. ${ }^{1}$ The present form of the verb, differing from the variant in Luke, might even point to the charismatic authority of Jesus still going on in his Church.

Other smaller points may be observed to buttress this view. In x. $24 \mathrm{f}$. the disciples are equated with their master, ${ }^{2}$ who after the healing of the dumb man, added by Matthew, was called Beelzebul (cf. ix. 34). In ix. 8 it is Matthew who speaks of the authority given to men, not merely to the son of man, ${ }^{3}$ whereas in xii. $7 \mathrm{f}$., where he is concerned with the interpretation of the Law, he retains, in contrast to Mark, only the saying about the son of man being lord of the sabbath, not the other saying that men are not created for the sabbath but enjoy the sabbath created for them. The story about the healing of the epileptic boy is shortened radically as against Mark; thus, the word of the father 'I believe, help my unbelief' is omitted, so that the whole pericope is focused on its end, which is considerably enlarged, namely on the teaching of the power of faith which, though it be small as a grain of mustard seed, yet will move mountains. ${ }^{4}$ Jesus' promise that nothing will be impossible to his disciples contrasts explicitly with the statement that it was impossible for them to heal the boy (verse 16 , cf. I9). Thus it is charismatic healing in which the authority of genuine faith is proved. ${ }^{5}$ It is true that the secondary ending of Mark, mentioning a long list of charismatic deeds, goes still further. It is difficult to decide how ancient this tradition is, or what its relation to other strata, even if we follow Dr F. Hahn's careful reasoning in its main lines. ${ }^{6}$ Finally, we should not forget that it is the mighty deeds of Jesus which call to repentance and faith in the first Gospel (xi. 20; xii. 18), and that it is Matthew who points, in a summary, to the healing of Jesus instead of to his teaching (xix. 12 as against Mark x. I ; cf. Matt. xiv. I4).

\footnotetext{
1 Held (see p. 214 n. 3), pp. 239 f. For the historical background cf. M. Hengel, Nachfolge und Charisma (1968), pp. $82 \mathrm{f}$.

a Verse 21 shows that persecution is the destiny of prophets, cf. D. R. A. Hare, The Theme of Persecution of Christians in the Gospel according to St Matthew (1967), pp. 137-41; J. Dupont, Les Béatitudes (1969), II, 317.

s Cf. H. Greeven, 'Die Heilung des Gelähmten nach Matthäus', Wort und Dienst, N.F. Iv (I955), 70. On the other hand, Matt. xii. 5-8 omits Mark ii. 27, because it deals with a case of authority for legal decisions.

- Cf. J. Duplacy, 'La foi qui déplace les montagnes', in: A la rencontre de Dieu (Mém. A. Gelin) ( 1961 ), pp. $273 \mathrm{ff}$.

5 It may be worth while mentioning the fact that the verb 'to heal' is preferred to 'to cast out the demon' in verses 16 and 18.

- Das Verständnis der Mission im N.T. (1963), pp. 53 f. Cf. below p. 229.
} 
If we agree with Dr B. Lindars' view (opposed to that of Dr Stendahl) that the formula quotations come from a broad early Christian tradition exceeding the realm of a 'school of Matthew', and with Dr R. Pesch's analysis of the introductory formulas, which proves that Matthew himself has formed and differentiated them in a characteristic way, ${ }^{2}$ we realize that these twelve passages of the Old Testament are particularly underlined by Matthew. What is emphasized by them? The most striking example is the second chapter with its four citations, to which a fifth one in iv. $14-16$ is to be added. The last one is undoubtedly redactionally inserted by the evangelist in order to prove that the move of Jesus from Nazareth to Capernaum, referred to in the very terms of the Old Testament text, has fulfilled the prophets. With regard to chapter ii, Dr Stendahl is certainly right in his emphasis on the movement of Jesus from Bethlehem by way of Ramah to Egypt and from there to Nazareth. ${ }^{3}$ Seeing that there is no scriptural proof for the last move, ${ }^{4}$ and that also the one from there to Capernaum cannot easily be proved from the scriptures, we may conclude that this is where the central interest of our Gospel lies. Might it be that, in this way, Jesus should be described from the very beginning as an itinerant prophet, the prototype of all future Christian prophets? Remembering how important it was in the church of the Didache and in Syria ${ }^{5}$ that following Jesus be literally imitated,

1 B. Lindars, New Testament Apologetic (196I), pp. I 5 f., 259-65; cf. also B. Gärtner, 'The Habakkuk Commentary and the Gospel of Matthew', St. Th. virI (1954), 1-24; R. H. Gundry, The Use of the Old Testament in St Matthew's Gospel (1967), pp. 151-9; N. Perrin, 'Mark xiv. 62: The End Product of a Christian Pesher Tradition?', $\mathcal{N}$.T.S. xII (1 $965 / 6$ ), $152 \mathrm{fr}$. (for Zech. xii. Io and Dan. vii. 13). W. Rothfuchs, 'Die Erfüllungszitate des Matthäusevangeliums', McDonald, 'The Use of the Old Testament in St Matthew's Gospel' and R. S. McConnell, 'Law and Prophecy in Matthew's Gospel: the Authority and Use of the Old Testament in the Gospel of St Matthew' have not yet been published. For Rothfuchs, cf. below p. 228.

The main reasons against a pre-Matthean collection of these quotations are: (a) The form of the text is different. In most cases it is a mixture of the Hebrew text (HT) and LXX. i. 23, however, is clearly LXX. xiii. 1 $3^{-16}$ is complemented (over against the Marcan parallel) according to LXX (cf. also the first line of xiii. 25). ii. 15 is probably interpreted in the light of Num. xxiv. 7 f. LXX. (b) The citations ii. I 5, I8; xxvii. $9 \mathrm{f}$. could not have been handed down without the stories in which they appear. (c) A mixture of $\mathrm{HT}$ and LXX is also to be found in other places in Matthew, e.g. in xxiv. 30, also xxvi. 31 (differently from Mark); xiii. $3^{2}$ and v. 33-5 (addition to the antitheses). (d) Influence of HT is to be seen also in xxiv. I 5 (beyond Mark's reference) and xi. 29; cf. x. $3^{6}$ (Matt.? $Q$ ?) and xvi. 27? (e) xxvii. 43 contains a phrase quoted from memory and influenced by LXX and its interpretation in Sap. ii. $(f)$ Quotations from LXX appear in sentences which could be Matthean-redactional (ix. 13; xii. 7,40 ; xxi. 16) or traditional (vi. 6). (g) In the background of xxvii. 9 there is a long history of tradition, in which both HT and LXX influenced the text in various stages (xxvi. 15 ; xxvii. 5 f.; Lindars 1 I $6 \mathrm{ff}$.) ; similarly in xxiv. 30 (Lindars $\mathrm{I} 22 \mathrm{ff}$; ; Perrin 152 ff.). (h) xiii. 32, too, is shaped by a long tradition, in which besides Psalm civ. 12 (HT?) Dan. iv. 12 LXX (Q) and Ezek. xvii. 23; xxxi. 6 LXX (Mark) were also creative.

2 'Der Gottessohn im matthäischen Evangelienprolog', Biblica XLvirI (I 967 ), 398 ff. Also Strecker (see p. 219 n. 2), p. 50 speaks of redactional introduction formulas, although he presupposes a collection of quotations from which Matthew draws his examples.

3 'Quis et unde? An Analysis of Mt. I-2', in: Judentum-Urchristentum-Kirche (for J. Jeremias), ed. W. Eltester (1960), pp. 94-105.

- Possibly Matthew is not aware of this; he might consider the quoted phrase (stemming probably from Judges xiii. 7; xvi. 17: E. Schweizer, Neotestamentica (1963), pp. 51-5; J. A. Sanders, 'NAZWPAIOS, in Mt. 2. 23, 7.B.L. Lxxxrv (1965), $169 \mathrm{ff}$.) an Old Testament text.

C. Cf. here p. 229. 
in giving up any fixed residence and wandering from place to place, we may consider this, at least, not impossible, although the quotations describe only the first stage of the life of Jesus.

The passages i. $22 \mathrm{f}$. and xxi. 5-7 depict, if Dr Pesch is not mistaken, ${ }^{1}$ the over-literal obedience to the commandment of the angel and the instruction of Jesus: Joseph refrains from sexual intercourse in order to fulfil the prophetic promise literally; Mary is to remain virgin beyond the time of conception as far as the time of birth. The disciples fetch two asses and set Jesus on both of them, because this is how the prophet wants it. This means that Matthew gives, with the aid of these quotations, the picture of the ideal disciple: 'And getting up he did as the angel of the Lord had instructed him'; 'And going on they did as Jesus had instructed them'. Two of the remaining citations prove Jesus to be the revealer of the hidden mysteries of God (xiii. I3-16 and 35), two more describe the charismatic healer, quietly restoring and not destroying (viii. I 7; xii. I 7-2I); a last one deals with the repentance of the disobedient disciple (xxvii. 9 f.). We may conclude, although we cannot reach any degree of certainty here, that the use of Old Testament quotations serves to urge the disciples to imitate the ideal of a charismatic itinerant prophet, following Jesus in perfect obedience.

That the life of the Church, understood as discipleship, is of first importance to Matthew is obvious. It is well known that the call to steadfastness with the relevant Old Testament prophecy of coming persecution has been transposed from the apocalypses of Mark and $Q$ to the sermon about the mission of the disciples (Matt. x. 2I-35). The new interpretation of the simile of the lost sheep, referring now to the duty of the disciple in the Church (Matt. xviii. I0-I4), finds its parallel in the word of the sheep without a shepherd, which describes, in Mark vi. 34 Jesus, in Matthew ix. 36 the disciples as shepherds of the flock. ${ }^{2}$ Probably Dr Lindars is also right in seeing, behind Matt. xvi. 18 , the saying of the stone of foundation becoming the stone of stumbling, because Peter is, according to Matt. xvi. I8, the stone of foundation, whereas Matthew, in xvi. 23, adds to the Marcan text: $\sigma k \alpha v \delta \alpha \lambda$ ov हl '̇uoũ, 'you are a stumbling-block for me'. ${ }^{3}$ If so, the originally exclusively Christological interpretation has been transformed into a reference to his disciple.

More relevant is the Matthean designation of the disciples as 'these little ones'. The term is probably of pre-Matthean origin. The saying about those who give a cup of cold water to 'one of these little ones' (Matt. x. 42) is also to be found in Mark ix. 4I, formed, however, as a direct address to 'you'

\footnotetext{
1 'Eine alttestamentliche Ausführungsformel im Matthäusevangelium', B.Z. x (1966), 220-45 and $\mathrm{xI}(1967), 79-95$.

a G. also Psalm viii. 3 in xxi. I 6 describing the praise of God by the 'little ones', who represent, in the view of Matthew, the church of the disciples of Jesus.

${ }^{3}$ Lindars (see p. 22 I n. I), pp. 18 I ff. Cf. J. Ringger, Begegnung der Christen $\left({ }^{8}{ }_{1} 960\right)$, pp. 27 I ff. for the use of this image in Hermas.
} 
and not containing the terms 'disciples' and 'these little ones'. Now, the transition from Mark ix. $4^{\mathrm{I}}$ to $4^{2}$ is the only break in a long chain of paraenetical words linked to one another by catchwords. If one presupposes that the Matthean form ( $Q$ ?) is the original one, then this isolated exception disappears. ${ }^{1}$ This might be supported by a further observation. In both Matthew and Mark this saying is connected with the other: 'Whosoever receives me, receives the one who has sent me', which is paralleled in Matthew by the word about receiving a disciple, in Mark by the one about receiving a child. ${ }^{2}$ This means that the two sayings (Matt. x. 40 and 42 ) were connected very early. ${ }^{3}$ They promise to the one who receives one of the disciples that he receives Jesus and so God himself. This is, then, interpreted by the following verse, which says that whosoever gives a cup of cold water to one of 'these little ones', will not lose his reward. This means that the designation of the disciples as 'these little ones' is both pre-Matthean and pre-Marcan, and that the interpretation referring to the reception of a child is secondary. This illuminates Matthew's understanding of discipleship. On the one hand, the term 'disciples' is, for him, identical with 'these little ones', as x. $4^{2}$ proves. On the other, he inserts the very suggestive verse $4^{1}$ : 'Whosoever receives a prophet in the name of a prophet, will receive a prophet's reward, and whosoever receives a righteous man... will receive a righteous man's reward.'4 Obviously, the terms 'prophet' and 'righteous' are taken up in verse 42 comprehensively in the terms 'these little ones' and 'disciples'. The disciple of Jesus is hence described in a twofold way: he is a prophet and he is a righteous man. ${ }^{5}$ This is very typical of Matthew. The first term refers to the charismatic activity of the disciple, the second one to his obedience towards God's Law as interpreted by Jesus. This is probably also the reason for the omission of the Marcan pericope of the foreign exorcist in a context in which he otherwise follows Mark closely: a charismatic healer who does not follow Jesus and the group of his disciples is unthinkable for Matthew. ${ }^{6}$

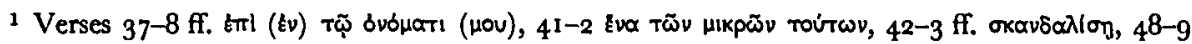

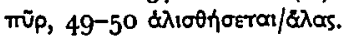

Luke $x .16$ might have, at the most, a material influence, if any. Formal parallels to Luke $x$ stop with Matt. x. I6.

- For the transition from a participle to a òs Ł\&v-clause cf. Matt. v. $3^{2}$ and xx. $3^{8} \mathrm{f}$.

- The style is assimilated to verses 40 and 42.

B As, in the view of Matthew, the pious men of the Old Testament: xiii. 17. iii. 15 also is redactional and typical of Matthew.

- Matthew would probably not have omitted this pericope because of the two sayings in $x .4^{\circ}$ and 42 , since he does not usually avoid doublets.
} 


\section{THE FINAL PARAGRAPHS OF THE}

\section{SERMON ON THE MOUNT}

We are now ready for an interpretation of the final paragraphs of the Sermon on the Mount, which contain the saying from which we started our investigation. In some way, the golden rule in vii. 12 is the actual end of this sermon, because, as $\operatorname{Dr} R$. Walker has seen, ${ }^{1}$ it forms, together with v. ${ }^{7} 7-20$, the brackets which include the interpretation of the Law. Once again, loving one's neighbour is recommended as the standard by which to understand the Law. This is the Law and the Prophets in a nutshell. The simile of the two ways asks the reader again and urgently to decide whether or not he will follow Jesus as his disciple. It is here that Matthew, in his own distinct terminology, ${ }^{2}$ inserts the warning against the false prophets ${ }^{3}$ coming in sheep's clothing, but actually as ravening wolves. ${ }^{4}$ They are, as we have seen, the preachers of óvouía, who seduce people to let charity cool off. Several points are thus clarified: (I) The false prophets are Christians, ${ }^{5}$ for they look exactly like the sheep in the flock. They are, therefore, those who, according to verse 22, will call Jesus Lord. (2) Their main attribute is the doctrine of óvoula, as xxiv. I I confirms. Because of it, in no way because of their charismatic activities, they will be condemned, as vii. 23 states. (3) This óvouia leads to lack of charity in the Church, that is to apostasy from the preacher of the Sermon on the Mount.

Particularly illuminating are the following verses $16-20$. Over against the Lucan form, Matthew intensifies the sharp warning of these verses in an extraordinary way by repeating, in verse 19 , the proclamation of the divine sentence by John the Baptist: 'Every tree which does not produce good fruit shall be felled and thrown into the fire.' This points to those doers of the ơvouia, who will be condemned as false prophets in spite of their 'Lord, Lord', for the two verses are interwoven by the context. ${ }^{6}$ Most interesting

1 Walker (see p. 2 I6 n. I), p. I35, against Barth (see p. 214 n. 3), p. 6g, who refers to vii. 15 ff. as the closing 'bracket'.

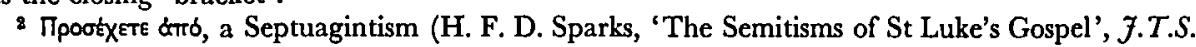
XLIV, 1943, 134) four times in Matthew against the Marcan $\beta \lambda \varepsilon \pi \varepsilon t \varepsilon$ dmo, in Luke three times (of which two contain Equrois as in LXX); only Matt. xvi. $6=$ Luke xii. I are based on the same Marcan passage. It is also Matthew who formulates the details of the image of the heretics as wolves, which in itself is traditional (Acts xx. $28 \mathrm{f}$., cf. Strack-Billerbeck $\mathrm{I}, 465 \mathrm{f}$., also Horace, Od. Iv. 4.50 and Gen. xlix. 27; Soph. iii. 3; Ezek. xxii. 27; Hab. i. 8; John x. 12; Did. xvi. 3; Ign. Philad. II. I f., further on the images of the people of God as a flock in the Old and New Testament). Evovura is to be found once in Q, six times (probably always in redactional passages) in Matthew.

${ }^{3} \mathrm{~J}$. Dupont, Les Béatitudes $\left({ }^{2} \mathrm{I} 958\right)$, i, $98-103$, considers the Lucan connection of xiii. ${ }^{23-7}$ (= Matt. vii. 13 f. and 22 f.) original. Thus it would be Matthew who inserted both sayings at their respective places and combined them with his attack against the false prophets. The changes in verse 22 are, therefore, probably also due to his redaction. Verse $2 \mathrm{I}$ is rooted in the tradition, as Luke vi. 46 shows, but has been altered by Matthew (Strecker (see p. 219 n. 2), p. 160).

4 Cf. O. Böcher, 'Wölfe in Schafpelzen', T.Z. xxrv (1968), 405 f.

5 Pace Walker (see p. 216 n. 1), p. i 36.

- Verse 16 refers to verse 15 , and verse 20 , taking up verse $16 a$, connects this warning against the false prophets with the verdict of verses $21-3$. 
is the fact that the real parallel to this part of the sermon in Luke's version (vi. $43-5$ ), is actually not this paragraph, but Matt. xii. $33-5 \cdot^{1}$ At the end of the Sermon on the Mount, Matthew uses the same material with a number of characteristic changes. First, he applies the image of tree and fruit explicitly to the false prophets. ${ }^{2}$ Second, he interprets it in a definitely ethical way. ${ }^{3}$ Third-and this is the most important change-his text in chapter vii, in contrast to both that in Luke and that in Matt. xii, ${ }_{4}^{4}$ refers no longer to the preaching, but to the behaviour of the false prophets.

The problem of the false prophets disturbed early Christianity quite a bit, and it was solved in very different ways, either by focusing on their ethical conduct, or on their Christological creed, or on their obedience to apostolic authority, or on the fulfilment of their prophecies, or on their communion with the Church..$^{5}$ According to Didache xi. 7 a church that interrupted the charismatic preaching of a prophet would be guilty of the sin against the Holy Spirit, and yet the same author is forced to give some ethical criteria by which to judge between wrong and right prophets. In a similar way, Matt. xii. $3 \mathrm{I}-7$ connects the simile of tree and fruit with a saying about speaking from the fullness of one's heart. He solves the problem by pointing to the coming Judgment, in which we shall be responsible for every word. In the Sermon on the Mount, however, he is solely interested in the ethical conduct of the false prophets and of the people seduced by them. Verse $2 \mathrm{I}$ insists on this point: Only doing the will of God will give entry into his kingdom, and will open the narrow gate. This shows that Matthew supposes that it will only be the Last Judgment that will reveal the true nature of the false prophets. ${ }^{6}$ This fits in with the little apocalypse, in which Matthew presupposes an activity of false prophets up to the time of the very end. The Old Testament phrase of prophesying in the name of Jesus is probably introduced by Matthew himself in order to connect this verse with the false prophets of verse $15 \cdot{ }^{7}$ Whether Matthew's reference to the charismatic works

1 Luke vi. 43 is taken up by Matt. xiii. $33 a, b$, not by vii. I 7, as is proved by the singular kapmov and the same adjectives in both places. Luke vi. 44 is equivalent to Matt. xii. $33 c$, while vii. 20 is formulated differently. Luke vi. 45 finally is to be found in Matt. xii. $34 b-35$, whereas it is missing in chapter vii. Only the parable of the thorns and thistles in Matt. vii. 16 is based on Luke vi. $44 b$.

Verse $16 a, \mathrm{cf}$. also cuiroús in verse 20.

3 Cf. the plural 'fruits' and the supplement ćya vi. 43 f., repeated also in Matt. xii. 33 and in the Gospel of Thomas). "Ayatóv and mounpóv appear also in Luke vi. 45 = Matt. xii. 35, though. Luke vi. 45; Matt. xii. 34-6; Gospel of Thomas 45.

- Did.xi. 7-1 2 (also Hermas, Mand.xi. 7-16); 1 Cor. xii. I-3 and I John iv. 2 ; Pseudo-Corinthians 3 ff.; Pseudo-Clem., Hom. II, 6-1 I.

${ }^{6}$ Matt. vii. 21 is probably the original wording (F. Hahn, Christologische Hoheitstitel $\left({ }^{2} 1964\right)$, p. 97; Strecker (see p. $219 \mathrm{n} .2$ ), p. 160). The acclamation kúple in verse 22 is very unlikely to go back to a word of Jesus himself, though; it might be taken up from verse $2 \mathrm{r}$ (in a pre-Matthean stage?). The sentence of the judge in verse 23 appears in Luke xiii. 27 in a quite different context, although also referring to the Last Judgment.

7 So H. T. Wrege, Die Überlieferungsgeschichte der Bergpredigt (1968), p. 148 . Otherwise it is very difficult to establish the priority of this or that form. Justin shows, in both passages, Apol. I. I6. I I and Dial. Lxxvi. 5, influence of the Matthean and the Lucan form (Wrege, pp. I $48 \mathrm{f}$.). "Avouias

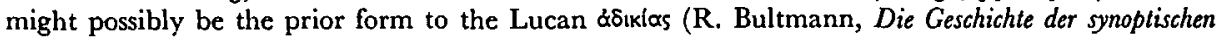
Tradition $\left({ }^{2} 1931\right)$, p. 122 n. 2). 
or that of Luke to eating and drinking with Jesus and to his teaching in the market-place is more original cannot easily be decided. I am inclined to vote for the former possibility, because Matthew, in the sentence of the judge, has preserved the original utterance of a prophet, as Hahn has made probable, and because Luke (or his tradition) may have changed the text in order to incriminate the unbelieving Jewish contemporaries of Jesus. ${ }^{1}$

The parable of the two houses is, in Matthew, even better linked with the context than in Luke, for the catchword moleiv is to be found seven times in Matt. vii. 1 7-22 and leads directly to the simile about the man who not only hears the words of Jesus, but obeys them also in his deeds. Finally Matthew closes the whole Sermon with a general sentence about the authority with which Jesus preached (vii. 28 f.). He found this word in Mark i. 22, but postponed it and transposed it to this place. In Mark it is what we should call in modern terms a kerygmatic proclamation for the benefit of the reader, which does not give him any material for checking its truth. In Matthew its truth is proved by the preaching of the earthly Jesus, which enables the reader to draw his own conclusions. ${ }^{2}$ Thus again Matthew leads his readers from a mere statement of the post-Easter Church to the teaching of Jesus himself, from which he may come back to the same position.

\section{THE CHURCH IN THE BACKGROUND OF THE FIRST GOSPEL}

We may summarize and try to sketch the image of the Church which guides Matthew in his writing. It seems to be clear that he is not sceptical at all about a charismatic life in the Church. On the contrary, following Jesus finds expression in charismatic deed in which his authority continues among his disciples. What are these charismatic deeds? Matthew presupposes healings and similar miracles still going on in the Church. In its preaching the Church is a Church of prophets. Just because the law of God leads to a better righteousness, imparting salvation only when interpreted by the teaching and the whole conduct of Jesus, it is necessary to decide ever anew in the concrete situation what this really means. Hence it is exactly the Matthean tradition in which we find most of those divine sentences uttered by early Christian prophets in the name of the exalted Christ which Dr E. Käsemann taught us to recognize. ${ }^{3}$ Matthew himself is still rather close to

1 Cf. Hahn (see p. 225 n. 6), pp. 96 f. and the alterations in Luke xxiii. $24-6$, by which the Jews become the executioners of Jesus (only in verse $3^{6}$ do we hear, for the first time, of Roman soldiers 'coming up'). ' Cf. E. Schweizer, 'Das Evangelium nach Markus', N.T.D. I ('1968), 27.

s 'Sätze heiligen Rechtes im Neuen Testament', N.T.S. I (1954/5), $248 \mathrm{ff}$., also in: Exegetische Versuche und Besinnungen (1964), II, $69 \mathrm{ff}$. Georg-Christoph Kähler, student at the Theological Faculty of Jena University, has, in an unpublished paper in August 1969 ("Das Matthäusevangelium als Rekonstruktionsbasis für die "Anfänge christlicher Theologie"?' [cf. Käsemann, loc. cit. pp. $82 \mathrm{ff}$. $=$ Z.T.K. LVII (1960), $162 \mathrm{ff}$.$] ), attacked Käsemann's position. He points to the formal parallels$ in proverbial exhortations of the Wisdom literature, for instance: 'God's punishment equals (man's deed)' - 'Whoever is too quick with an oath, meets a quick death' - 'Whocver insults women in the presence of another person, will be insulted by them at his own burial' (H. H. Schmid, Wesen 
this view; for, as we have seen, he expects that it will be only in the Last Judgment that the false prophets will be unmasked, or that good and evil will be separated, as is shown in his parables. The figure of Jesus interpreting by God's own authority $H$ is will to men and bringing them the divine healing power is central in his Gospel, and forms the prototype of the prophet who has no place to dwell but wanders from town to town. Thus, Dr Kilpatrick's view of the function of the prophets in the service of the early Church ${ }^{1}$ should be modified in so far that we should rather think of itinerant prophets, similar to those mentioned in the Didache, who would bring God's directives to the churches. Matthew is far from legalism; he knows that new interpretations are necessary in new situations. This is shown, first of all, by the great commission at the end of his Gospel, which in the new post-Easter situation annuls the ruling of Jesus against going to Samaritans and Gentiles. ${ }^{2}$ Matthew sees the disciples of Jesus far removed from any merely literal obedience to the law as codified in the scriptures and in the Pharisaic tradition, or even in the sayings of Jesus himself when rigidly fixed in a similar way.

Here, however, the problem arises. As early as $1929 \mathrm{Dr}$ A. Schlatter formulated: 'The standard to distinguish between genuine and false prophecy given to (the Church of Matthew) is its communion with Jesus.'3 However highly Matthew esteems the true prophets, he can issue the sharpest warnings against the false prophets who in the name of the exalted Christ proclaim a post-Easter gospel which becomes more and more separated from the example and the teaching of the earthly Jesus. The pivotal point, which decides about true discipleship or apostasy from Jesus, is charity as acted and taught by Jesus. Wherever it cools off or is in danger of becoming unimportant, it is the result of false prophecy, not of genuine prophecy in the und Geschichte der Weisheit ( 1966 ), Qu. 2c, 27b, pp. 203, 220); Prov. viii. $35 a$; x. $9 a$; xvii. I 3; xix. 16a; xxi. 21 (if not corrected); xxii. 8 ; xxvi. $27 b$ LXX; Tob. xiil. 6; Sap. vi. 1 $a$; Test. Seb. v. 3 ; viii. I, 3 . In these examples different patterns should certainly be distinguished, for instance: (1) whoever gains $x$, gains $y$; (2) whoever behaves $x$ (adverb), behaves $y$ (adverb); (3) whoever practises $x$, will find $x$; (4) whoever acts $x$ (noun or adverb), will be given $x$ (noun or adverb); (5) whoever $x$ (verb), will be $x$ (verb) by God (or: God will $x$ him). However, the references given by Kähler show that the pattern of these sentences is rooted in sapiental exhortation and has influenced statements of the ius talionis in a secondary way only, that immanent and eschatological punishments are blending into each other, and that the idea of an eschatological judgment is also found in paraenetic contexts (and against Käsemann, p. 75, not simply as a secondary development). Kähler is right in emphasizing that the pattern of a 'Satz heiligen Rechtes' in itself does not prove the existence of early Christian prophets; it could also stem from sapiental exhortation. None the less, the Pauline letters and the Apocalypse prove that Christian prophets used this pattern in order to stress the severe judgment on Doomsday (cf. I Cor. iii. 17 etc.: '... will destroy...'; Mark viii. $3^{8 \text { : }}$ 'Son of man'; Matt. v. I9: 'Kingdom of heaven'), whereas the parallels are usually used in a positive way. This shows that the pattern has been 'apocalypticized', and it is only to be discussed (with Kähler) how far this goes back to early Christian prophets, how far to Matthew's redaction.

1 The Origins of the Gospel according to St Matthew ( $\left.{ }^{2} \mathrm{r} 950\right)$, p. 126.

2 For Matt. x. 5 f., 23 cf. H. Schürmann, 'Mt. 1o, 5-6 und die Vorgeschichte des synoptischen Aussendungsberichtes', in: Neutestamentliche Aufsätze (für J. Schmid) (1963), pp. 270 ff., and idem, 'Zur Traditions- und Redaktionsgeschichte von Mt. Io, 23', B.Z. III (I959), 82 ff. For Matt. xxviii. 18-20 cf. Vögtle, Studia Evangelica, II, (see p. 2 I 8 n. I.), pp. 234 f.

s Die Kirche des Matthäus (1929), p. 8. 
name of Jesus. Hence the church of prophets is of necessity always also the church of righteous men.

This means that the true prophet is the interpreter of the commissions of Jesus, hence a scribe trained for the kingdom of heaven, bringing out of his treasure new and old instruction (xiii. 52). He proclaims with prophetic authority what the instruction of Jesus means in the present situation of his Church. Such authority to bind and loose is, ${ }^{1}$ according to xvi. I9, given to Peter as the leader of the Church. It is, according to xviii. I8, given in principle to every member of the Church. Thus Peter shows, according to Jesus' will, in an exemplary way who the disciple of Jesus is to be: the man who follows Jesus, strictly bound to his instruction and yet interpreting it ever anew. Rightly, Dr Walker emphasizes ${ }^{2}$ that Peter is certainly not a mediating authority, a founder of new tradition, but a disciple instructed by Jesus himself, using the authority which is given to every true disciple to interpret Jesus' word for the present time. It is therefore not surprising that chapter xviii, collecting the rules given by Jesus to his Church for its daily life, does not contain any allusion to special leaders as distinguished from other members of the Church, like presbyters or bishops. It speaks only of 'these little ones'. Every one of them is urged to go after an erring brother, to speak to him, first in privacy, then together with one or two others (in order to fulfil the Mosaic regulations), and finally to try to win him back with the aid of the whole assembly of the Church. Every one of them is urged to act as the good shepherd seeking the lost sheep, as Jesus himself had once acted. Every one of them is urged to forgive in an unlimited way; that is to exercise charity, as Jesus wanted it. Hence to every one of them is also given the authority to bind and loose. ${ }^{3}$ The result of this understanding of the prophetic authority of the Church is seen, for instance, in the antitheses of the Sermon on the Mount, where we still detect how the original logia were applied ever anew to practical problems arising in the life of the Church. ${ }^{4}$

In this way the Church has listened to Jesus' voice ever anew. It goes without saying that outstanding individuals have contributed to this process more than others. The author of the Apocalypse, for instance, does not claim any special title or position, but introduces himself as 'brother'. And yet he most certainly exercises, owing to the extraordinary authority of his preaching, an influence which goes far beyond that of others, although in his Church every one might be a prophet or even is, in some sense, a prophet. The situation was probably similar in the Church from which Matthew comes.

1 This means, at least in the understanding of Matthew, probably more than forgiving or nonforgiving (cf. J. A. Emerton, 'Binding and Loosing-Forgiving and Retaining', 7.T.S. xIII (1962), $325-31$ ). Authority of doctrine and authority of discipline cannot be strictly distinguished, though.

${ }_{2}$ Walker (see p. 216 n. 1), p. 118 .

3 Very similarly Schlatter, Die Kirche des Matthäus, pp. 22 ff.

- E. Schweizer, Neotestamentica (1963), pp. $404 \mathrm{ff}$. 
Some members are given the prophetic and charismatic authority in a particular way. They are likely to be the ones who wander from church to church so that their gifts serve as many brethren as possible.

To summarize: the Church by which the first Gospel is shaped is the body of 'these little ones' who are ready to follow Jesus; to remain obedient to the law of God as interpreted by Jesus' deeds and words; to reinterpret his instructions ever anew in answer to practical problems; to proclaim his word in this way, letting it speak to present situations, and to revive his miraculous power in healings. There is one authority only in this Church, Jesus' own words and deeds, interpreting the Law of God. They come to life ever anew in the event of prophetic proclamation, which formulates doctrine for the life of the Church, and in charismatic action, which heals the sick and casts out the demons. Teacher and prophet are to a considerable degree still one. One could even say that every disciple is both prophet and teacher, though the stress laid on this or that gift may be different. Some particularly gifted members of the Church are probably following Jesus in a more literal way, continuing his itinerant life, wandering from place to place to serve and to teach the Church. This is, I think, approximately the picture of the Church presupposed in the first Gospel. It finds its continuation in the Christian communities which we find in the Didache and, for a long time more, in the Church of Syria. ${ }^{1}$

Addenda: Since the MS was completed the following contributions to our problem have been published:

I. Rothfuchs (see p. $22 \mathrm{I} \mathrm{n.} \mathrm{I).} \mathrm{We} \mathrm{agree} \mathrm{in} \mathrm{the} \mathrm{explanation} \mathrm{of} \mathrm{v.} 18$ (p. $5 \mathrm{I}$ ), in attributing introduction, form and selection of the formula quotations to Matthew (pp. 88 f., 92 f., I04 f., I 79 f.), in seeing the emphasis of the quotations in the central part of the gospel on the life and ministry of Jesus (p. I03) and in opposing Strecker's 'historicizing ' understanding of Matthew (pp. I 7983). While not denying that the citations in ch. 2 stress the activity of God (p. IоI), I see their main purpose differently.

2. E. Linnemann, 'Der (wiedergefundene) Markusschluß', Z.T.K. Lxvi ( 1969$), 255-87$. While authors even before her considered Matt. xxviii. 9 f., I $6 \mathrm{ff}$. as containing materially the lost end of Mark (e.g. Schweizer (see p. 226 n. 2), p. 212), and Mark xvi. I5-20 as of old, even pre-Matthean origin (e.g. Hahn, see p. 220 n. 6), she identifies parts of Matt. xxviii. 16 f. and Mark xvi. 15-20 with the original ending of Mark. If she were right, a certain reluctance of Matthew to speak about charismatic miracles (Mark xvi.

I H. Köster,' 'TNWMAI $\triangle I A \Phi O P O I$ ', Z.T.K. (1968), 169-72, 183-90, and particularly G. Kretschmar, 'Ein Beitrag zur Frage nach dem Ursprung frühchristlicher Askese', Z.T.K. LXI (1964), 32-49; for Matthew cf. also pp. 53-61. Cf. also G. Quispel, Makarios, das Thomasevangelium und das Lied von der Perle ( 1967$)$, especially pp. 6, 21 f., 37, 47, 1 1 0 . This church differs from that under Pauline influence by its understanding of a life in charity and even asceticism as a fulfilment of God's commandment, not as a 'gift' (I Cor. xii. 3 ; ; vii. 7) and from Jewish-Christian groups by its openness to the Gentile world and its non-interest in relatives of the earthly Jesus. 
I7 f.) would be obvious. This is conceivable, since Matthew presupposes certainly charismatic activities in the church, but does not emphasize this topic in the same way as he explicitly does with the observance of the law.

3. K. Tagawa, N.T.S. xvI, I 49-62. His suggestion to start from the social background of the evangelist both in the nation of Israel and in the Christian church is very helpful. In my view, however, it does not suffice to solve the problems. The coming of all nations (into Israel, I agree) implies that the disciples do go 'on the road of the Gentiles and into the town of the Samaritans' (x. 5), in order to call men into an Israel that is no longer separated from the heathen world by food regulations (xv. II). The Matthean combination of viii. I I $f$. with the story of a believing Gentile centurion (in contrast to the unbelieving Israel) certainly stresses this very contrast so that the understanding of the rejected 'sons of the kingdom' as Christians is hardly possible. 